DOI https://doi.org/10.32837/app.v0i65.311

УДК 323.1:930.85 «18/19»

A. I. Сушко

ORCID ID: https://orcid.org/0000-0001-5755-7844

кандидат історичних наук,

доцент кафедри політичних теорій

Національного університету «Одеська юридична академія»

O. О. Каретна
ORCID ID: https://orcid.org/0000-0002-7408-7546
кандидат політичних наук,
доцент каредри соціологї̈ та психологї

\title{
ФОРМУВАННЯ ПОЛІТИЧНОЇ КУЛЬТУРИ В ПЕРІОД МОДЕРНІЗМУ
}

Постановка проблеми. Соціокультурні аспекти устрою суспільства, особливо періоду модернізації, усе більше привертають увагу науковців. По суті, модерн сформував сучасну Європу як посттрадиційне суспільство, якому притаманний динамізм соціокультурної сфери завдяки збільшенню ролі інтелектуально-духовної сфери.

Автори вважають, що теоретично поняття «політична культура» варто розглядати в широкому значенні, яке дозволяє включати в їі склад як базові елементи, так й ідеї, переконання, що стосуються взаємодії політичних інститутів суспільства. Сам процес історичного дискурсу розглядається в соціокультурному контексті. Показ трансформації в українському суспільстві другої половину XIX - початку XX ст. під впливом ідей і цінностей модернізму дозволяє більш чітко і всебічно з'ясувати особливості процесів соціокультурного розвитку України перехідного періоду, а також суть нашого сучасного буття.

Виділення не вирішених питань. Потребує подальшого дослідження проблема формування політичної культури українського народу під впливом зовнішніх чинників, наприклад, в умовах світової війни, конфлікту цивілізацій тощо, що зумовлює появу тї своєрідних форм.

Розпочато процес осмислення найбільш дієвих моделей політичної культури сучасності, що історично склалися, з потребами новітнього часу, інтересами і цінностями, які притаманні соціокультурним процесам постіндустріального суспільства.

Мета роботи - проаналізувати процес становлення політичної культури нашого суспільства у складних умовах трансформації соціальних інститутів періоду модернізації. Дослідити особливості змін, форм прояву і збереження у складі двох імперій самобутності політичної культури українців.

Огляд основних досліджень. Науково-теоретична необхідність дослідження ролі та місця політичної культури нації як чинника становлення сучасного суспільства і правової держави, іï інститутів досить чітко окреслена у працях К. Добіжи, В. Корнієнка, Б. Сороки, Г. Щедрової та інших.

Розгляду історичних процесів, які найбільш суттєво впливали на розвиток української політичної культури, присвячені праці Б. Цимбалістого, О. Рудкевича та М. Гутора.

Автори в сучасних умовах приділяють все більше уваги у своїх працях досвіду «культурного повороту» 1990-2000 рр., зокрема досягненням у межах концепції нової культурної істоpiї. Так, усе більше уваги звертають на аналіз соціокультурного світу України такі науковці, як: Л. Малес, А. Сокурянський, М. Юрій, Л. Нагорна. Цивілізаційне осмислення культурних процесів в Україні грунтовно досліджено у працях В. Андрющенка, Я. Калакури, М. Михальченка, О. Рафальського, В. Шийка.

Виклад основного матеріалу. 3 Нового часу йде постійний процес зростання впливу інтелектуально-культурної сфери на соціальну динаміку Європи. Модерність породжує суспільство, у якому втілені ідеали епохи Просвітництва та прогресу науки. Власне, модерн стає важливим періодом європейської історії із XVII ст. до початку XX ст., без сумніву, це важливий 
етап культурної історії світу, що має ключове значення для осмислення подій суспільного і культурного життя всіх європейських народів, зокрема й України.

Модернізм як загальнокультурна течія на межі XIX-XX ст. визнавав пріоритет сучасного над традиційним, підтримував постійне оновлення всіх сфер буття. Нове в цьому контексті стає продуктом передусім розумових здібностей людини, отже, продуктом прогресу. Розгортаються процеси модернізаційного характеру - індустріалізація, урбанізація, масова освіта. Звичайно, і Австро-Угорська i, особливо, Російська імперії були на стадії початкової модернізації. Так, в останній більшість населення було неграмотним і проживало в сільській місцевості. Модернізація, яку здійснювали в основному панівні нації імперії, посилювала асиміляційні процеси, доводила до кризового стану традиційні цінності інших народів. Захист своїх інтересів ставав важливим завданням для української інтелігенції і приводив до становлення політичного націоналізму.

Одним із визначних чинників українського націотворення стало відродження національної культури. Цій меті допомагала і діяльність просвітницьких та наукових осередків. Зокрема, «Руської трійці», громад, товариств «Просвіта», Наукового товариства ім. Шевченка й інших інституцій. Важливою була роль преси в розвитку української культури і процесах самостановлення модерної української нації. Так, у кінці XIX ст. виходило всього 13 часописів і жодного з них на території Російської імперії, а вже в 1912 р. видавалось 12 українських газет і журналів, а всього понад 80 часописів (Калакура та ін., 2015, с. 336). Усі ці осередки українського суспільно-політичного і культурного життя виступали на захист рідної мови, літератури, освіти, займались виданням навчальної і науково-популярної літератури. Одним із напрямів цієї діяльності стає конструювання власного минулого, зазвичай під впливом ідей романтизму. Підгрунтя шукали і в народній творчості, і у традиціях різних регіонів України, що посприяло формуванню образу ідеальної Вітчизни, романтичному уявленню про козацтво і часи Гетьманату. В історичних працях все більше уваги звертали на часи Київської Русі і Галицько-Волинського князівства, аналізували, серед іншого, і трагічний досвід втрати власної державності. Історично соціокультурна цілісність України-Русі була суттєво порушена після XIV ст., коли наші землі увійшли до складу кількох сусідніх держав. Водночас починається процес європеїзації південно-західних, а потім й інших частин України. Політична культура, яка формується під впливом як об'єктивних, так і суб'єктивних етнополітичних характеристик, стає частиною діалогу двох культур, а точніше, реалізацією однієї з фундаментальних форм - взаємодії через конфлікт. Війни і політичне протистояння ведуть до інтенсивного запозичення в супротивника значних культурних елементів. Зазвичай інокультурний матеріал дестабілізує вітчизняну національну культуру і суспільство, яке, ініційоване запозиченим, стає більш агресивним. У момент максимального засвоєння інокультурного матеріалу, тобто перед частковим переродженням суспільства, що модернізується, протистояння досягає апогею. Відбувається трансформація часописів (Юрій, 1997, с. 147).

На постсоціалістичному просторі Україна належить до країн із найбільш тривалим транзитом, до того ж із відхиленням у русі. Фактично наша країна перебуває між консолідованої демократією і напівавторитарним режимом. На думку більшості дослідників, транзит є концептом, що стосується змін політичного режиму і має початок та закінчення. Інколи його трактують як синонім трансформації або переходу, що залежить від значення, яке вкладають в це поняття різні автори. У свою чергу, трансформацію як концепт використовують стосовно об'єктів зі складною структурою, що суттєво змінились, зазвичай на краще. Траєкторія суспільно-політичних трансформацій в Україні має тривалий період і в певні відрізки часу має менш визначений характер, порівняно із країнами, у яких транзит закінчився консолідацією демократії і побудовою правової держави.

Політизація українського соціуму на базі національної ідеї розпочинається із другої половини XIX ст. в Австро-Угорській і Російській імперіях. Цей період для Європи визначальний, коли на перший план в індустріальному і соціально-культурному розвитку виступають головні суб'єкти Нового часу - політичні нації та їх політичні об'єднання. На цій основні в майбутньому будуть формуватись союзи європейських держав та суперечності між ними. Зразком побудови власне національної держави стає Німеччина, панівна еліта якої на чолі 
з О. Бісмарком реалізує ідею держави, у якій індивідуум і нація виступають як єдине ціле. Інституціональна відмінність від сусідів полягала в тому, що німецькі землі до другої половини XIX ст. залишались роздробленими.

Прагнення до національного самовизначення намагалися реалізувати і народи без держави, передусім чехи і поляки. Зі згаданими націотворчими процесами пов'язана і доля українців, які за перебування у складі двох різних імперій переживали національне відродження розрізнено. Ця неоднаковість умов дає про себе знати в період радикальної зміни суспільно-політичних порядків у Центральній і Східній Свропі на завершальному етапі Першої світової війни.

Порівняльна характеристика соціокультурного становища українців в обох імперіях свідчить про те, як воно формувало політичну культуру. Наявні в ній патріархально-провінційні риси поєднувалися з активізмом, відчуттям колективізму. У Галичині, порівняно з підросійською Україною, ефективніше йшов процес оформлення політичних доктрин, формування політичних партій, а особливо різних інституцій громадянського суспільства, зокрема й господарсько-економічного характеру, що розвивало і накопичувало суспільний досвід, уміння орієнтуватися в політичному просторі.

У Наддніпрянській Україні перевагу віддавали ідейно-політичній роботі, намагалися через агітацію впливати на масу. Поява Братства тарасівців, створення політичних партій, події революції 1905-1907 рр. вносили суттєві зрушення в політичне життя. Політизація українського руху сприяла зростанню політичної свідомості й активності українців, водночас посилився і вплив політичної культури на суспільно-політичні процеси загалом. Особливо масштабно все це спостерігалося під час Першої світової війни, коли чітко проявилися всі ознаки і структурні елементи політичної культури нашого народу, сильні і слабкі сторони його менталітету. Війна супроводжувалась помітним прискоренням процесу трансформації українського етносу східних і західних земель у націю. На думку Я. Грицака, безпосередні контакти між українцями з обох боків фронту їх зближували, прискорювали кристалізацію національної ідеї часописів (Грицак, 1996, с. 259). Розпочинається період світових війн і революцій, які демонтували і Російську, і Австро-Угорську імперії. Відновлення державності України, поява іï знову на карті Європи справили величезний вплив на політичну свідомість нашого народу. Трансформується соціум, динамічнішим стає процес формування української модерної нації, політична культура якої набуває все більш сучасного виміру.

У рамках соціогуманітарного пізнання все більше процес історичного дискурсу розглядається в культурному контексті, імперативом часу стає концептуальність - необхідність вивчати будь-яке історичне явище в контексті того соціокультурного середовища, яке його породило. «Сучасна епістемологія рішуче відмовляється від пошуку універсальних теоретичних конструктів, придатних для аналізу історії різних часів і народів», - стверджує Л. Нагорна. Зрозуміти спосіб мислення людини минулого і рамки ії «життєвого світу» можна лише через той культурний контекст, у якому ӥй судилося існувати (Нагорна, 2014, с. 116). Тому закономірні скепсис науковців щодо можливостей створення загальної теорії соціокультурної еволюції й оптимізм стосовно перспективи порівняльного аналізу культурних традицій у віддалених одна від одної тисячоліттями (Нагорна, 2014, с. 117).

Узагалі історична пам'ять досить функціональна і має власну циклічність у різних соціально-історичних умовах. Так, трансформаційні процеси кінця XIX - початку XX ст. підвищували інтерес до власного історичного минулого, унаслідок чого зростає самосвідомість соціуму.

Епоха модерну радикально змінює релігійні й етнічні ідентичності, формує націю. Цей процес потребував зусиль із боку інтелектуальної еліти, яка розробляла концепцію нації і поширювала її через пресу та систему освіти. Перевага нації над іншими ідентичностями в ії взаємодії з конкретними індивідуумами, які мають характерні особливості та законні інтереси. Права особистості підкріплювалися аналогічним концептом національних прав.

Протягом XIX ст. відбувається процес народження модерної української нації, що спричинило виникнення націоналізму. У цей період він пройшов у саморозвитку три фази: етнічну, національної ідентичності інтелектуальної еліти українського суспільства, а наприкінці XIX ст. оформляеться в ідеологію і політичний рух, завдання якого було типовим для націоналізму Східної Свропи - перетворити народні маси на націю. Ідеологічне і політичне 
оформлення українського націоналізму на межі XIX-XX ст. спровокувало і могутні соціальні чинники (Касьянов, 1998, с. 48). Свропа стає найбільш динамічною соціальною системою, яка у XIX ст. виросла на базі домінування ідеалів європейської культури. У цій спільноті панують уніфіковані соціальні та культурні зв' язки, а саме поняття модерну порівнюють із поняттям індустріалізму і протиставляють традиційному суспільству.

Культурно-духовні процеси модернізму не обмежились сферою мистецтва. Усі галузі суспільного життя зазнали суттєвого впливу настанов модернізму, було сформовано особливий тип свідомості. Філософія культури витіснила традиційну соціальну філософію. Базовими поняттями, на яких почали формувати розуміння сутності людини та ії місця у світі, стали поняття раси, народу, землі, життя тощо. Досить швидко теоріям організованого суспільства був програмно протиставлений соціальний анархізм, який став базою діяльності політичних партій, груп і окремих особистостей. У цьому контексті розроблялось сприйняття таких категорій людського існування, як «життя» і «смерть». Остання категорія в модернізмі набуває естетизованого змісту, як і філософія війни. Тому концепт особливого типу індивіду домінує. Це - героїчна особистість, спроможна здійснювати високе покликання - будувати нове суспільство, творити нову культуру.

Загалом, соціокультурні та політичні зміни в Європі, отже, і в Україні в подальшому суттєво вплинули на культурно-духовне життя і політичну діяльність. Так, український рух із середини XIX ст. все більше набуває загальнонаціонального характеру й еволюціонує з культурно-просвітницького до національно-визвольного з політичним спрямуванням.

Криза традиційних цінностей породжує і різні види маргінального існування з його формами соціального нетерпіння, запереченням існуючих соціальних інститутів. Маргінали є соціальною базою тероризму, зокрема і революційного, особливо коли їхня система цінностей поширюється на інші соціальні групи населення, що є основою політичних переворотів і революцій. Треба розуміти, що рівень політичної культури суспільства, як і окремих груп, індивідів, передусім визначається мірою перетворення ідейно-ціннісних настанов на конкретну політичну дію, а показником рівня політичної культури стає ступінь ії інституціоналізації. Це нормативно організоване політичне відношення, що включає всю багатоманітність суспільно-політичних організацій, які формують соціальні інтереси. Поведінка індивідів у рамках політичної системи вважається інституційною, якщо вона відповідає зразкам і нормам, що дрмінують у даному суспільстві. Вони можуть прийматись добровільно, а якщо їх нав' язувати, то виникає відчуження, що дестабілізує ситуацію в соціумі та державі.

На відміну від росіян, українці формувались в інших соціокультурних координатах. Київська Русь була частиною європейської цивілізаційної спільноти. Велике князівство Литовське, Річ Посполита тісно пов' язані із західноєвропейськими цінностями. Новий час політично об'єднав українців і росіян у межах однієї держави. Центр поєднання - віра, в інших аспектах - розбіжності, тому імперія стала стирати відмінності методом асиміляції, що спричинило певну аморфність у громадсько-політичній та культурній діяльності українців, які проживали в Російській імперії, на відміну від тієї частини, що була під владою Австро-Угорщини.

Закономірно, що частина українців убачали в державі лише насильника, а ідеалом життя ставав вільний козак. Це породило масовий рух анархізму під керівництвом Нестора Махно, різні прояви отаманщини під час революційних потрясінь 1917-1920 pр.

Революційна ідеологія формувалась у свідомості мас на межі XIX-XX ст. як відкидання демократичного вирішення проблеми різноспрямованості інтересів, радикальним засобом практичного втілення цінностей та ідеалів. Водночас консерватизм частини діячів національного руху виступав як гарант наступності в політиці, запорукою уважного ставлення до досвіду попередніх епох, зокрема Руїни (XVII ст.), Коліївщини (XVIII ст.), проти спрощення соціальної реальності. Ліві ідеологи розглядали це як нерішучість у політичній поведінці, консервування відсталості. У цій ситуації досить складним є пошук консенсусу, співучасті в суспільно-політичній діяльності. Досвід чітко показав, що без компромісу в умовах трансформації суспільства пройти цей шлях без суттєвих втрат неможливо.

Отже, у рамках модерну відбуваються глибокі соціокультурні зміни в Україні, які помітно впливали на характер мислення більшості людей. Традиційний позитивістський світогляд 
XIX ст. змінювався модернізмом, він приділяв увагу духовним цінностям і життєвим практикам людей, які до цього визнавалися маргінальними. Навіть більше, і звичні поняття наповнювались іншим змістом у рамках філософії культури. Процес життєдіяльності людини на основі системності, впорядкованості, етики скромної праці та філософії малих справ змінювався руйнуванням рутини людського життя. Ії місце зайняла енергія пориву, творчого життя індивіда, нескованого обов' язками відповідальності та порядку. Цей підхід активно проникав і у сферу політичної культури, де все помітніше місце посідають поняття свободи творчості особистості, незалежності від побуту, зверхнє ставлення до буденності. Представникам суспільно-політичних рухів життя мислилось як цінність, що заповнена боротьбою, творчістю, утіленням ідеалів досить утопічного характеру. Звичайно, у цьому був протест проти тогочасного способу життя, базованого на розрахунку, практицизмі, проти підпорядкування людини жорстоким стандартам поведінки. Але однозначно формується підхід до становлення особливого типу індивіда, який буде стверджувати новий устрій життя, зокрема і тоталітаризм XX ст. в різних його версіях.

Висновки. Еволюційний розвиток українського суспільства проходить складний шлях трансформаційних змін із подальшою модернізацією. Перехід від традиційного суспільства до сучасного завжди досить драматичний через протидію, різні ускладнення, конфлікти політичних сил. Аналіз транзитних змін, зокрема в період модерну, засвідчує, що в Україні на пріоритетне місце виходить поряд із політичною трансформацією і соціокультурний процес, у якому політична культура стає важливим чинником усіх цих змін.

У даний період уперше і теоретично, і практично відбувається складний процес творення з етносу політичної нації як суцільного культурного організму, що спроможний на самостійне і політичне життя. Об'єднання українських етнічних земель починає розглядатися через поняття «єдність» і поступово трансформується в реальний рух, пов'язаний із національним відродженням і боротьбою за відновлення державності. Ця ідея на межі XIX-XX ст. поєднується з концептом політичної незалежності України, що стала базою для становлення сучасної держави.

\section{Лiтература:}

Грицак Я. Нарис історії України. Формування української модерної нації XIX-XX століття. Київ, 1996. Калакура Я., Рафальський О., Юрій М. Українська культура: цивілізаційний вимір. Київ, 2015.

Касьянов Г. Украӥнський націоналізм: проблема наукового переосмислення. Украӥнський історичний журнал. 1998. № 2.

Нагорна Л. Історична культура: концепт, інформаційний ресурс, рефлексивний потенціал. Київ, 2014. Юрій М. Етногенез та менталітет українського народу. Київ, 1997.

\section{References}

Gry'czak Ya. (1996) Nary's istoriyi Ukrayiny'. Formuvannya ukrayins'koyi modernoyi naciyi XIX-XX stolittya [Essay on the history of Ukraine. Formation of the Ukrainian modern nation of the XIX-XX centuries]. K.

Kalakura Ya., Rafal's'ky'j O., Yurij M. (2015) Ukrayins'ka kul'tura: cy'vilizacijny'j vy'mir [Ukrainian culture: the dimension of civilization]. $\mathrm{K}$.

Kas'yanov G. (1998) Ukrayins'ky'j nacionalizm: problema naukovogo pereosmy'slennya [Ukrainian nationalism: the problem of scientific rethinking]. Ukrayins'ky'j istory'chny'j zhurnal [Ukrainian historical journal], № 2. Nagorna L. (2014) Istory'chna kul'tura: koncept, informacijny'j resurs, refleksy'vny'j potencial [Historical culture: concept, information resource, reflective potential]. K.

Yurij M. (1997) Etnogenez ta mentalitet ukrayins'kogo narodu [Ethnogenesis and mentality of the Ukrainian people]. K.

\section{Анотація}

Суико А. І., Каретна О. О. Формування політичної культури в період модернізму. - Стаття.

У статті розглянуто поняття політичної культури як визначального чинника в соціокультурному житті українського суспільства кінця XIX - початку XX століття, запропоновано визначити єдність цінностей та інтересів українського етносу як запоруки для формування політичної нації і власної держави. Ці глибокі соціокультурні зміни помітно впливали на характер мислення більшості людей, по суті традиційний позитивістський світогляд Нового часу змінюється на цінності й ідеали періоду модернізму. Варто розуміти, що рівень політичної культури суспільства, як і окремих груп, індивідів, 
визначається мірою перетворення ідейно-ціннісних настанов на конкретну політичну дію, а показником рівня політичної культури стає ступінь ії інституціоналізації. Це нормативно організоване політичне відношення, що включає всю багатоманітність суспільно-політичних організацій, які формують соціальний інтерес. Політизація українського соціуму на базі національної ідеї розпочинається iз другої половини XIX століття в Австро-Угорській та Російській імперіях. Це період для Свропи визначальний, коли на перший план в індустріальному, соціально-культурному розвитку виступають головні суб'єкти Нового часу - політичні нації та їх політичні об'єднання. Усі ці процеси впливали і на становлення політичної культури українського народу. Особливо масштабно вони проявилися під час Першої світової війни, коли визначились всі ознаки і структурні елементи політичної культури нашого народу в даний період, сильні і слабкі сторони його менталітету. Війна супроводжувалася помітним прискоренням процесу трансформації українського етносу східних і західних землях у модерну націю, політична культура якої набуває все більш сучасного вигляду. Загалом, соціокультурні та політичні зміни в Свропі, отже, і в Україні, у подальшому суттєво змінили культурно-духовне життя всіх частин України і політичну діяльність партій та груп. Так, український національний рух усе більше в даний період набуває загальнонаціонального характеру й еволюціонує з культурно-просвітницького до національно-визвольного з політичним спрямуванням.

Ключові слова: політична культура, трансформація, модернізм, соціокультурні зміни.

\section{Summary}

Sushko A. I., Karetna O. O. Formation of political culture in the period of modernism. - Article.

The article considers the concept of political culture as a determining factor in the socio-cultural life of Ukrainian society in the late nineteenth and early twentieth centuries, proposed to define the unity of values and interests of the Ukrainian ethnic group as a guarantee for the formation of a political nation and state. These profound socio-cultural changes have markedly influenced the thinking of most people, and in fact the traditional positivist worldview of the New Age is changing the values and ideals of the modernist period. It should be understood that the level of political culture of society and certain groups and individuals is determined by the degree of transformation of ideological and value attitudes into a specific political action, and an indicator of the level of political culture is the degree of its institutionalization. This is a normatively organized political relationship, which includes all the diversity of socio-political organizations that form the social interest. It was the beginning of the politicization of Ukrainian society on the basis of the national idea that began in the second half of the XIX century in the Austro-Hungarian and Russian empires. This is a defining period for Europe, when the main subjects of the New Age - political nations and their political associations - come to the fore in industrial, socio-cultural development. All these processes influenced the formation of the political culture of the Ukrainian people. They were especially large-scale during the First World War, when all the signs and structural elements of the political culture of our people in this period, the strengths and weaknesses of its mentality were determined. The war was accompanied by a marked acceleration of the process of transformation of the Ukrainian ethnos in the eastern and western lands into a modern nation, whose political culture is becoming more and more modern. In general, socio-cultural and political changes in Europe, and, accordingly, in Ukraine in the future significantly changed the cultural and spiritual life of all parts of Ukraine and the political activities of parties and groups. Thus, the Ukrainian national movement is increasingly in this period acquires a national character and evolves from cultural and educational to national liberation with a political orientation.

Key words: political culture, transformation, modernism, socio-cultural changes. 